\title{
Marketing And The Rise Of Web 2.0: Expanding Opportunity, Increasing Challenge
}

Peter A. Rosen, University of Evansville, USA

Mark H. Phillips, Abilene Christian University, USA

\begin{abstract}
As the Internet has become an increasingly central element of daily life, marketers have scrambled to adapt their methods to this new medium. While early online marketing efforts consisted primarily of repackaged print materials, the rise of Web 2.0 sites with their increasingly interactive experiences has forced marketers to broaden their offerings in order to remain relevant. This analysis considers the broad dimensions of the new online marketing landscape. It assesses the major Web 2.0 sites and evaluates their current scope and reach, concluding that firms utilizing Web 2.0 tools for marketing purposes must insure consistency across their various sites, invest adequate resources to provide prompt service, and recognize that customer expectations for such service will continue to rise for the foreseeable future.
\end{abstract}

Keywords: marketing; e-commerce; Web 2.0; Facebook; Twitter; advertising

\section{INTRODUCTION}

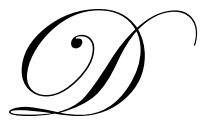

espite its relatively recent appearance, the worldwide network, known as the Internet, has already evolved through multiple iterations. In its original, noncommercial form, the Internet delivered such fundamental abilities as email (1971), chat sessions (1973), and ftp file downloads (1973) (Hafner \& Long, 1996). As the growing network evolved from its original form as a military tool through its use as an academic research forum, its sponsors maintained a strict policy prohibiting commercial use (Bazewski, 1992). Not until 1994, when a new network backbone became available, could the newly liberated commercial Internet begin its meteoric expansion (Merit, 1994). The arrival of the World Wide Web provided the final piece of the puzzle (Berners-Lee, 1999) and the race to earn profits online had begun.

In its earliest incarnation (Web 1.0), the Internet was limited by both its incomplete adoption and its rudimentary capabilities. The lack of ubiquitous broadband connections severely constrained the content which could be delivered, but as Internet adoption increased, observers quickly concluded that a new "gold rush" was at hand. Online advertising garnered a relatively small \$30 million per quarter in 1996, tripled in 1997, doubled in 1998, and tripled again in 1999 (PricewaterhouseCoopers, 2005). Despite the dot-com bust of the early twenty-first century, users continued to migrate online, and as connections became faster, the network continued to evolve. Observers soon noted a significant change, from the largely static "1.0" incarnation to a new, more interactive network they dubbed "Web 2.0" (O'Reilly \& Battelle, 2004). For firms engaged in creating or purchasing marketing services, this change would fundamentally alter the landscape of their efforts.

This analysis will first discuss the state of Web 2.0 in current marketing efforts. It will then assess several of the largest Web 2.0 sites, examining how they are currently being used and the results they are producing. Finally, it will offer recommendations for firms wishing to employ these technological tools for their own commercial purposes. 


\section{WEB 2.0}

Enterprises are now using Web 2.0 in many different ways to connect with customers, employees and other stakeholders. Web 2.0 has been defined as a "new breed of application, which runs primarily on Internet servers and company intranets, is generally understood to be dynamic (that is, content updates automatically) and collaborative (drawing information from multiple sources and from user contribution), embracing a new paradigm, the Internet itself becomes the computing platform" (Schindler, 2007). The technologies themselves vary widely; examples include Facebook, Twitter, YouTube, Wikipedia, Blogger and Flickr. While Web 2.0 is not a newer version of the Internet, the idea that users are now the ones providing content on the Web makes it much different than its largely passive predecessor.

The information security company McAfee recently commissioned a global study on Enterprise Web 2.0, examining how corporations are making use of these new technologies. The study of more than 1000 companies worldwide found that three out of four organizations currently use Web 2.0, and that common marketing uses include sales, customer relations, and advertising and public relations (McAfee.com, 2010).

To demonstrate the popularity of Web 2.0, five of the top ten most visited websites are Web 2.0 sites, including Facebook (\#2), YouTube (\#3), Blogger (\#6), Wikipedia (\#8), and Twitter (\#10); the other five top sites are all search engines (Alexa.com, 2010). In addition to current usage, the Gartner Group, an IT consulting firm predicts that by 2014, social networking - a type of Web 2.0 technology - will replace email as the primary vehicle for interpersonal communications for $20 \%$ of business users (Pettey, 2010). According to Facebook's metrics, $86 \%$ of Fortune 100 Global companies currently use some form of Web 2.0 technology and $99 \%$ of all online retailers plan to have a Facebook page by 2011 (Facebook.com, 2010a).

The "ability to generate new revenue streams" was cited by $75 \%$ of the respondents of the McAfee study as the most significant force behind enterprise Web 2.0 adoption. Other important drivers for adoption include market pressure from customers to adopt the technology and benefits like crowd sourcing, in which customers help companies find problems to solutions and improve the design of their products (McAfee.com, 2010).

With the popularity of Web 2.0 among customers, and the benefits companies can potentially realize through the use of these technologies, future growth seems inevitable. This analysis will examine the current uses of Web 2.0 by organizations, focusing on Facebook, Twitter, virtual worlds, and blogs to demonstrate possible marketing uses of Web 2.0.

\section{Facebook}

Facebook is a social networking website with over half a billion registered users, 200 million of which access the site through mobile devices. According to the site's statistics, Facebook users spend 700 billion minutes per month on the site and have an average of 130 friends (Facebook.com, 2011). In other words, Facebook users are well connected, spend a lot of time on the site, and are users of mobile technology. To reach these users efficiently, companies need to expand their marketing efforts to include previously non-traditional marketing channels like social networking websites and text messages.

Advertising on sites like Facebook is an easy way for companies to reach a massive consumer population. In 2009, companies spent over $\$ 800$ million on Facebook ads alone, with a total of $\$ 1.68$ billion spent across all social networking sites (Hansen, 2010).

Facebook ads are effective for two reasons: they offer the ability to segment users and reach a specific target market, and they employ a user's own friends to enhance the ads. One example of this would be a wedding photography business. If the target market for this business is engaged women, 24-30 years old, who live in a certain geographical area, Facebook can use the text from the user's profile to correctly place the ad only on the pages of users who fit that target demographic (Facebook.com, 2010b). 
Facebook allows companies to generate free pages which are "customizable presences for an organization, product, or public personality [like a CEO] to join the conversation with Facebook users." Pages allow individual users to become Fans of businesses they admire. Posts by an organization using its Page will start to appear in the News Feed of the Fan, giving organizations a better way to reach their Fans (Facebook.com). As of late 2010, Starbucks' page has nearly 19 million Fans, and includes numerous interactive features designed to bring Fans back to the site. Fans can buy a Starbucks gift card or coffee online, check the balance on a gift card, see special events that Starbucks is having online or in its stores, or even 'check in' from a local store, a process which uses the GPS on a mobile device to show the user's actual location in her Facebook status. Checking in allows a user's Facebook friends to know where a person is at any given time, and companies like Starbucks benefit from the increased exposure that checking in brings.

Facebook ads can then be combined with Pages to leverage the connection between individual users. Ads with a social context can be created in such a way that interactions such as the following occur: User A is friends with User B. User A is a fan of a particular organization, (e.g. Starbucks). If User B sees a Starbucks ad on her page, she will also see a message in the ad indicating that User A is a Fan of Starbucks and she should join as well (Keane, 2010). These social context ads are powerful ways to leverage the power of connections and lets individuals become brand advocates.

\section{Twitter}

Across the nation, millions of people use Twitter, the social networking site that allows registered users to send and receive messages (or tweets) of up to 140 characters. Twitter has become the communication tool of choice for politicians, celebrities, and forward thinking business organizations.

To illustrate the recent popularity of the site, Twitter is now the 10th most popular website in the United States, and boasts over 175 million registered users, who generate 95 million tweets per day (Twittter.com, 2011). This growth has been rapid. A recent Nielsen Report states that Twitter climbed to 18.2 million unique visitors in May 2009, up from 1.2 million a year earlier, for an increase of 1448\% (McGiboney, 2009).

A Gartner Report highlighted four ways businesses are currently using Twitter:

1. Direct communication - organizations use the site as a public relations channel or marketing tool by sending out messages about new products or offers;

2. Indirect communication - company employees use the site to enhance their own reputations and thereby enhance the company's reputation;

3. Internal communication - the site can be used as an information and idea exchange tool between employees of the same organization;

4. Inbound signaling - the site can be used to gauge public opinion about a company and its products (Pettey, 2009).

In the area of direct-to-customer tweeting, Dell creditd its Twitter account (DellOutlet) for helping to sell $\$ 3$ million worth of PCs to its over 600,000 followers (Miller, 2009a). Starbucks communicates with its 366,000 followers by publicizing deals and asking for customer feedback. The company credits its idea for the splash sticka device designed to prevent coffee spilling from the sip hole-- to its social networking sites, including Twitter (Petrecca, Howard, \& Horovitz, 2008). JetBlue and United Airlines offer last minute discount fares to fill unsold seats. In the case of JetBlue's Cheeps through Twitter (Jones, 2009), followers are notified on Monday and have eight hours to book tickets for the following week. Food trucks across the country are crediting Twitter for increased revenues, as customers can now keep track of these mobile restaurants (Bergman, 2009). Small businesses of all types are benefitting from the increased exposure Twitter can provide (Miller, 2009b).

Zappos.com, a leading online shoe, clothing and handbag company, has embraced social networking sites like Twitter as a way to increase revenues and improve internal communication. CEO Tony Hsieh encourages all of his employees to embrace technology, and personally owns a blog, Facebook page, and Twitter account with over 1.7 million followers. Nearly 500 Zappos employees maintain Twitter accounts, and Mr. Hsieh celebrates this by 
hosting a website that lists the names and number of followers for each employee (zappos.com, 2011b). His passion for the benefits of the site has led to the creation of a how-to guide for employees who want to get started on Twitter (zappos.com, 2011a). He maintains a company blog along with his COO, and touted the benefits of microblogging in a post entitled "How Twitter Can Make You a Better and Happier Person" (Hsieh, 2009). Hsieh believes that more employees on Twitter will translate to greater popularity for the retailer. If employees are posting messages about how happy they are with the organization, this free publicity can translate to increased revenues for Zappos.

Best Buy is an example of a company that has embraced Twitter for both internal and indirect communication methods. Best Buy has created an internal network of over 24,000 employees called the Blue Shirt Nation who network, problem solve, and collaborate using technologies like Twitter (ReadWriteWeb, 2008). A company-sponsored website, Best Buy Connect, consolidates and tracks the Twitter feeds of its employees. Employees are also allowed to contribute posts to the official company Twitter account-twelpforce (bestbuy.com, 2011).

Companies like Domino's Pizza and Amazon.com have used Twitter to diffuse recent crises. Domino's responded on Twitter to a YouTube.com video showing two of its employees playing with the ingredients of a pizza in a way that disgusted many loyal customers. Amazon.com used Twitter to respond to allegations that sales rankings had disappeared for gay and lesbian books (Clifford, 2009). Using sites like Twitter Search, companies can gather intelligence on themselves, spot trends in product and company mentions, and respond to crises in a much faster way than ever before.

Whether Twitter is used for direct communication to enhance customer service, indirect communication where employees enhance the reputation of the company, internal communication where top management communicate with employees or employees collaborate, or inbound signaling where companies track about what is being said about them, this simple short-message service is a powerful marketing tool.

\section{Blogs}

Blogs are websites featuring regular entries of commentary, descriptions of events, or media such as video. Blogs can be geared toward a particular topic area, can act as online diaries or can be used to disseminate information. Blogs commonly use Real Simple Syndication (RSS) to push updated content to users on any device or technology that acts as an RSS reader. Blogs also allow readers to post comments and leave feedback about other blog posts.

Corporate blogs differ from personal blogs in that they are maintained by businesses and can be used internally to share information, or externally for public relations, customer service and marketing functions. Some corporate blogs are maintained by the CEO of the corporation, while others are authored by lower level employees. Some companies actually pay consumers, whether in money or in sample merchandise, to test their products and blog about their experiences. Examples of each will be provided in the following section.

Marriott International's Chairman and CEO Bill Marriott authors posts for the corporate blog - Marriott on the Move. Organized by date and by topic, the posts span such diverse areas as education, politics, sports, technology, food, travel and the books, movies, television and media he has read, listened to, or watched. Marriott also discusses the company's various hotel brands and the merits of each. Corporate blogs maintained by the CEO convey credibility to the contents, but may not drive revenues as well as those maintained by consumers or lower level employees. CEO blogs are often viewed as more of a public relation tool or a commercial, and consumers are less likely to trust these blogs than they would those of a recommendation from a personal friend or a consumer who blogs about the products or services a corporation provides (Nielson.com, 2009).

Sony offers a blog where PlayStation players can connect, download product demos, and join conversations about products. Users can submit and vote on ideas for improving the products, which is an example of a concept called crowd sourcing. Gamers return to the blog regularly to get updated information on current and future products, building a strong following (Sony, 2009). 
Wal-Mart has created a blog site for corporate buyers called Check Out: Where the Lanes are All Open (Barbaro, 2008). This team of bloggers shares its knowledge of the products found in Wal-Mart stores without being censored by the corporation. Because buyers have more expertise on a particular set of products than anyone else in the organization, their posts appear credible. These expert opinions, Wal-Mart believes, will help drive sales by giving consumers all the information they need to make an informed purchase.

Dawn Meehan is a consumer and opinion leader who maintains a blog called "Because I Said So Reviews." She is currently working with corporations like American Express, Kellogg's, and Canon, among many others, to review products on her blog. Subscribers to this blog trust her opinion to be unbiased and she indicates that she is giving honest accounts and opinions of the products and services she is testing (Meehan, 2010). She not only provides product and service information, but the corporations that provide products to test also supply products to give away to her blog subscribers. The giveaways are for subscribers who comment about her blog posts, so the corporation she is partnering with not only gets her product review but comments from other consumers who have used the product.

\section{Virtual Worlds and Virtual Goods}

"Virtual worlds can be defined as environments created by technology that incorporate virtual representations of various elements found in the real world. Among those elements are virtual human beings (avatars) with whom one can interact, virtual physical environments that include land and oceans, and virtual objects like chairs and tables" (Kock, 2008). Some of the more popular virtual worlds include Second Life and massively multiplayer online role playing games (MMPORPG) like World of Warcraft. One report places the number of virtual world users as high as 1.1 billion across more than 175 different virtual worlds; commerce on Second Life, just one of these virtual worlds, was approximately half a billion dollars in 2009 (Keegan, 2010). Virtual goods that are sold for physical money originally included land and clothing, and have now expanded to items like cars and cell phones. Virtual goods are sold in virtual worlds and on other Web 2.0 sites; Facebook, which accounted for $\$ 835$ million of these sales in 2009, was the fastest growing segment of the virtual goods market. The overall market for virtual goods in the United States was \$1.6 billion in 2009, with that number expected to rise to \$2.1 billion dollars in 2011 (Helft, 2010).

Nissan is one company that invested in the virtual world Second Life. The company bought an island in Second Life for $\$ 1,250$ and spends another $\$ 195$ per month in rent. The company's programmers built a huge test track, featuring a gigantic vending machine which dispenses cars for virtual test drives. Those relatively insignificant costs along with some billboards and other promotional costs to drive users to the island, account for the total marketing expense necessary to generate such a virtual presence (Siklos, 2006).

Clothing companies like Nike, Reebok and American Apparel are setting up virtual store fronts where users can purchase virtual clothing and shoes for their avatars; the store fronts also drive users to the firms' online websites to purchase physical products. These companies are also test-marketing new designs and getting feedback from Second Life users. Sony BMG constructed rooms on its Media Island devoted to its most popular artists; one of the firm's new artists, Ben Folds, is holding a virtual concert on the island. These ventures will be tied to websites where users can purchase downloads of the music they hear in the virtual world (Siklos, 2006).

\section{RECOMMENDATIONS}

As the Internet becomes increasingly viewed as an "appliance" which is routinely used without conscious thought, technical performance gains will become less important while the user experience will become the dominating force in the net's evolution (Hanson \& Kalyanam, 2007; Norman, 1998). Within this arena, marketers will need to keep several constraints firmly in mind if they wish to succeed.

First, as consumers observe others successfully using technology, their expectations rise. Online consumers increasingly expect to be able to shop, compare, purchase, and repair or service products and services on company sites, at least in part because they are regularly exposed to instructional video and other content created by amateurs, which demonstrates that such content is not difficult to provide (Hann, 1999; Tenopir, 1998). 
Second, firms will be forced to improve their coordination across functional areas (Hanson et al., 2007). While information has traditionally been controlled and disseminated by a centralized marketing function, firms today often find themselves providing information from numerous functional groups, including technical staffs which have little public relations experience. Coordinating a unified message across time zones or continents will become both increasingly import and increasingly difficult. Consumers will reasonably expect that the information they receive from a company's various departments will be consistent and coherent.

Third, users will increasingly expect personalized experiences and they will demand timely responses to queries and requests. While eliminating telephone support may provide cost savings, many firms are discovering that providing useful service via email is actually a much larger task. In an example cited by O'Connell (1998), one large consumer products company successfully handled $85 \%$ of its 264,000 monthly phone calls, while managing to respond to only $10 \%$ of its 20,000 email inquiries. The anecdotal benchmark for email response appears to be 24 hours (Tyler \& Tang, 2003), with slower replies requiring an explanation of the delay. This informal benchmark may remain applicable to email, but with personal communication increasingly moving to text and instant messaging, customer expectations of corporate response times will undoubtedly shorten.

Fourth, customers will increasingly expect that in addition to consuming content, they will also help create it. From basic online product reviews, to product development forums, to other venues in which customers' wants and desires drive product development, buyers are increasingly in the mood to help shape the offerings they see. Firms such as BzzAgent exist to introduce marketing firms to individuals who voluntarily review and comment on products, in many cases for no compensation beyond the provision of a sample item. BzzAgent's army of associates now numbers more than 750,000, and their clients include multiple Fortune 500 firms (BZZAgent, 2011). As individuals sign up with word-of-mouth firms to covertly market to their friends, the line between friendship and sales will increasingly blur, and customers will move even further into the already blurry region between buyer and seller.

The era of the monolithic ad buy has passed. The days when a firm could simply dump its marketing budget into television and print outlets are a distant memory. Marketing to the Web 2.0 generation will require greater creativity, greater flexibility, and more complete transparency. The tremendous opportunities offered by Web 2.0 technologies will be matched by comparably difficult challenges, forcing marketers to relearn the skills that have served them well for many decades.

\section{AUTHOR INFORMATION}

Dr. Peter A. Rosen is an Associate Professor at the University of Evansville, 1800 Lincoln Avenue, Evansville, IN 47722 USA. He teaches Management Information Systems courses and his research interests include social networking, Web 2.0, and HRIS issues. He may be reached at pr7@evansville.edu.

Dr. Mark Phillips is an Assistant Professor at Abilene Christian University, ACU Box 29338, Abilene, TX 79699 USA. He teaches Strategic Management, the capstone course for business majors, as well as Marketing. His research interests include trust, management education, and strategy. He may be reached at mhp04a@acu.edu.

\section{REFERENCES}

1. Alexa.com; Top sites; http://www.alexa.com/topsites.

2. Barbaro, M.; Wal-Mart unleashes employes in blogs; http://www.nytimes.com/2008/03/03/business/worldbusiness/03iht-walmart.1.10639013.html.

3. Bazewski, P. 1992. The rules of the internet. Benchmarkes, 13(5): 12.

4. $\quad$ Bergman, B. 2009. Tweeting Food Truck Draws L.A.'s Hungry Crowds.

5. Berners-Lee, T. 1999. Weaving the web: The original design and ultimate destiny of the World Wide Web by its inventor. New York Harper-Collins.

6. bestbuy.com. 2011. Connect to read and be read.

7. BZZAgent; About BzzAgent; http://about.bzzagent.com/word-of-mouth/index/about-bzzagent. 
8. $\quad$ Clifford, S.; Video prank at Domino's taints brand;

http://www.nytimes.com/2009/04/16/business/media/16dominos.html.

9. $\quad$ Facebook.com; Facebook Pages; March 2009;

http://www.facebook.com/advertising/FacebookPagesProductGuide.pdf.

10. Facebook.com; Roundup of the Top Internet and Social Media Statistics; http://www.facebook.com/note.php?note_id=446557287372\&comments\&ref=mf.

11. Facebook.com; Facebook Ads: Reach over 500 million people where they connect and share; http://www.facebook.com/advertising/?

12. Facebook.com; Press Room: Statistics; http://www.facebook.com/press/info.php?statistics.

13. Hafner, K. \& Long, M. 1996. Where wizards stay up late: The origins of the Internet. New York: Simon \& Schuster.

14. Hann, L. W. 1999. E-commerce can create unexpected challenges. Best's Review (January 1999$): 87$.

15. Hansen, K.; U.S. advertising on social networks surges $20 \%$ to $\$ 1.68$ billion, half of it on Facebook; http://latimesblogs.latimes.com/technology/2010/08/social-media-advertising-facebook.html.

16. Hanson, W. \& Kalyanam, K. 2007. Internet marketing and e-commerce. Mason, OH: Thomson Higher Education.

17. Helft, M.; Virtual Goods Expected to Grow by 40 Percent Next Year, Study Says; http://bits.blogs.nytimes.com/2010/09/28/virtual-goods-expected-to-grow-by-40-percent-next-year-study$\underline{\text { says/. }}$

18. Hsieh, T. 2009. How Twitter can make you a better (and happier) person.

19. Jones, C.; JetBlue and United give Twitter a try to sell airline seats fast; http://www.usatoday.com/travel/flights/2009-08-02-jetblue-united-twitter-airfares_N.htm.

20. Keane, M.; Nielsen: Facebook ads work great — if you've already got fans on the network; http://econsultancy.com/us/blog/5778-nielsen-facebook-ads-work-great-if-you-ve-already-got-tons-of-fans.

21. Keegan, V.; Virtual worlds: is this where real life is heading?; http://www.guardian.co.uk/technology/2010/aug/22/discover-virtual-worlds-revolution.

22. Kock, N. 2008. E-collaboration and E-commerce in virtual worlds: The potential of Second Life and World of Warcraft. International Journal of e-Collaboration, 4(3): 1-13.

23. McAfee.com; Web 2.0: A complex balancing act; http://newsroom.mcafee.com/images/10039/Web2report.pdf.

24. McGiboney, M.; Nielson's Social Media quickTake: May 2009; http://blog.nielsen.com/nielsenwire/wpcontent/uploads/2009/06/nielsen_pr_090619.pdf.

25. Meehan, D.; Because I said so reviews; http://dawnmeehan.blogspot.com/.

26. Merit; Update on transition from the NSFNET backbone; http://www.merit.edu/mail.archives/nanog/199410/msg00000.html.

27. Miller, C. C.; Dell says it has earned $\$ 3$ Million from Twitter; http://bits.blogs.nytimes.com/2009/06/12/dell-has-earned-3-million-from-twitter.

28. Miller, C. C.; Marketing small businesses with Twitter; http://www.nytimes.com/2009/07/23/business/smallbusiness/23twitter.html.

29. Nielson.com; Personal Recommendations And Consumer Opinions Posted Online Are The Most Trusted Forms Of Advertising Globally; http://blog.nielsen.com/nielsenwire/wpcontent/uploads/2009/07/pr_global-study_07709.pdf.

30. Norman, D. 1998. The invisible computer. Cambridge, MA: MIT Press.

31. O'Connell, P. L. 1998. We got your e-mail; Just don't expect a reply, New York Times (July 6, 1998).

32. O'Reilly, T. \& Battelle, J. 2004. Opening welcome: State of the Internet Industry, Web 2.0 Conference. San Francisco, CA.

33. Petrecca, L., Howard, T., \& Horovitz, B.; Ad Track: Starbcks splash stick says no to sloshing; http://www.usatoday.com/money/advertising/adtrack/2008-04-13-ad-track_N.htm?csp=N008.

34. Pettey, C.; Gartner highlights four ways in which enterprises are using Twitter; http://www.gartner.com/it/page.jsp?id=920813.

35. Pettey, C. 2010. Gartner reveals five social software predictions for 2010 and beyond. Gartner Newsroom.

36. PricewaterhouseCoopers. 2005. IAB Internet Advertising Report: An industry survey: 5.

37. ReadWriteWeb. 2008. Best Buy's "Enterprise Twitter". 
38. Schindler, E.; Web 2.0 Definitions and Solutions;

http://www.cio.com/article/101614/Web_2.0_Definition_and_Solutions.

39. Siklos, R.; A virtual world but real money; http://www.nytimes.com/2006/10/19/technology/19virtual.html?_r=1\&sq=second.

40. Sony; PlayStation Store Update; http://blog.us.playstation.com/.

41. Tenopir, C. 1998. Plagued by our own success. Library Journal, 123: 39-40.

42. Twitter.com; Twitter is the best way to discover what's new in your world; http://www.twitter.com/about.

43. Tyler, J. R. \& Tang, J. C. 2003. When can I expect an email response? Paper presented at the ECSCW '03: European Conference on Computer-Supported Cooperative Work.

44. zappos.com; Beginner's quick start guide and tutorial to using Twitter; http://twitter.zappos.com/start.

45. zappos.com; Twitter.zappos.com; http://twitter.zappos.com/employees. 